\title{
薬学研究を拓くホワイトバイオテクノロジーの最前線
}

芝崎誠司, ${ }^{*}, a$ 植田充美 $b$

\section{The Frontiers of White Biotechnology and the Development of Pharmaceutical Sciences}

\author{
Seiji SHIBASAKI ${ }^{*, a}$ and Mitsuyoshi $\mathrm{UEDA}^{b}$ \\ ${ }^{a}$ Department of Pharmacy, School of Pharmacy, Hyogo University of Health Sciences, 1-3-6 Minatojima, \\ Chuo-ku, Kobe 650-8530, Japan, and ${ }^{b}$ Division of Applied Life Sciences, Graduate School of \\ Agriculture, Kyoto University, Kitashirakawa-oiwake-cho, Sakyo-ku, Kyoto 606-8502, Japan
}

21 世紀が既に 10 年が経過した現在，便利で快適 な暮らしを享受してきた先進国の人々は，このよう なライフスタイルを提供してきた先進技術へさらな る期待を持ちつつも，持続的かつ地球環境への負担 の少ない社会や産業のあり方に，より関心を向け始 めている. 中でも人類の活動の根幹に係わるエネル ギ一問題に関しては，従来の化石燃料からバイオマ ス由来エネルギーへの大転換を迎えようとしてお り，これまでの生活水準を維持するのに必要なエネ ルギー資源の創出に注目が集まっている.さらに, 様々な化成品の製造において化石燃料に依存してき た化学産業は, 微生物や酵素を用い環境に調和した 物質変換技術，いわゆるホワイトバイオテクノロ ジーへと技術革新を迫られている. 読者の方には, 微生物や生体由来の酵素を用いた物質変換や物質生 産は，現代に始まったことでないことを指摘される かもしれない.もっとも，ホワイトバイオテクノロ ジ一は, 医薬品・食品素材を始めとする各種発酵産 業を長年にわたりリードしてきた. 今日のホワイト バイオテクノロジーに至るまでの背景と, 近年の特 徵について少し概観してみたい.

伝統的なスクリーニング手法に基づいた，自然界 からの有用物質生産微生物や酵素の探索は, 時代を 問わずこの研究分野の基盤をなすものである，得ら れた微生物や酵素は, 変異体の作出を経て, より高 効率な目的物質の生産に供されてきた。現代では,

$a$ 兵庫医療大学薬学部医療薬学科（干650-8530 神戸市 中央区港島 1-3-6), $b$ 京都大学大学院農学研究科応用 生命科学専攻 (下606-8502 京都市左京区北白川追分町) *e-mail: seiji@huhs.ac.jp

日本薬学会第 130 年会シンポジウム S55 序文
遺伝子工学的手法による酵素の部位特異的な変異手 法が，基質特異性や活性の改変をもたらし，網羅的 な改変による最適な微生物や酵素の調製が可能とな

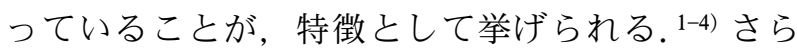
に生物機能の網羅的改変技術の 1 つとして，コンビ ナトリアル・バイオエンジニアリングという研究分 野が挙げられる．この非常に魅力的な手法により， ゲノム情報を最大限に活用することはもとより, 微 生物ゲノム情報をツールとして，ゲノム情報にコー ドされていない機能まで作り出してしまう技術も生 まれている。 また，IT やナノテクノロジー技術の 急速な進展に伴って，マイクロチャンバーアレイな どのハイスループットスクリーニング系が考案され ており, 5) 複雑な多段階反応産物や変異体ライブラ リーから，望む性質を有する細胞や酵素のクローン を精密に選択する技術も利用可能となっている. 今 日のホワイトバイオテクノロジーの研究の流れか ら, ここ数年以内に思いもよらない革新的で, 環境 に調和したモノづくり技術6)が出現し，医薬品製造 や開発に資するツール7が続々と生み出されること が予感されるぐらい，活気あふれる魅力的な分野で あることがお分かり頂けると思う.

130 年会における本シンポジウムでは, 幅広い分 野の生命科学研究者より, ホワイトバイオテクノロ ジーに基づく様々な研究手法や応用例, さらに, 新 しいホワイトバイオテクノロジーとして将来が期待 される新技術やシーズが紹介された。その内容は, 微生物酵素を用いた中枢神経疾患の検出系, カロテ ノイド生産微生物の探索とその特性, ビタミン B12 代謝機能の解明につながるシステム酵素学, 新規ア ミノ酸リガーゼによるオリゴペプチド合成，酵母分 
子ディスプレイによる物質変換系，醗酵天然物から の医薬品開発，ファージディスプレイによる抗体酵 素の高活性化，分子ディスプレイによる有機溶媒内 酵素反応など，極めて多岐にわたるテーマであり， いずれもこれまで化学法に頼ってきた技術やプロセ スに新しい概念をもたらすインパクトのある取り組 みである，当日ご参加頂けなかった薬学会会員諸氏 にも是非ご紹介したく，本シンポジウムに登壇頂い たシンポジストの方々に，同内容を総説として再現 して頂いた．多忙な中，執筆を引き受けて下さった シンポジストの皆様に，この場をお借りして感謝申 し上げたい。このように各テーマが誌面に再現され たことで，ホワイトバイオテクノロジーの幅の広さ と奥深さ，そして薬学研究を拓く技術として将来へ の展望が鮮明になったと思われる。また，本企画を 通して, 薬学研究, 創薬分野に携わっておられる読 者にホワイトバイオテクノロジーが目指すところを 感じ取って頂き，今後も関心を持ってご注目頂くこ とができれば幸いである.

\section{REFERENCES}

1) Shibasaki S., Ueda M., Yakugaku Zasshi, 129, 1275-1276 (2009).

2) Ueda M., Tanaka A., Biotechnol. Adv., 18, 121-140 (2000).

$3)$ Shibasaki S., Ueda M., Recent Pat. Biotechnol., 3, 19-27 (2009).

4) Ueda M., "Frontier of Combinatorial Bioengineering," CMC Publishing Co., Ltd., Tokyo, 2004.

5) Fukuda T., Shiraga S., Kato M., Suye S., Ueda M., Biotechnol. Prog., 22, 944-948 (2006) .

6) Inaba C., Maekawa K., Morisaka H., Kuroda K., Ueda M., Appl. Microbiol. Biotechnol., 83, 859-864 (2009).

7) Shibasaki S., Sakata K., Ishii J., Kondo A., Ueda M., Appl. Microbiol. Biotechnol., 80, 735-743 (2009). 